\title{
Literary and Analytical Study of the Source Plants of Kshara (Alkali) for Ksharasutra Preparation in the Management of Fistula-in-ano
}

\author{
G.V.P. Samaranayake ${ }^{1 *}$, W.A.L.C. Walivita ${ }^{2}$, K.M. Chandimal ${ }^{3}$ \\ ${ }^{1}$ Department of Ayurveda Basic Principles, Gampaha Wickramarachchi Ayurveda Institute, University of Kelaniya \\ University Kandy Road Kelaniya, 11600, Sri Lanka \\ ${ }^{2}$ Department of Chikitsa, Gampaha Wickramarachchi Ayurveda Institute, University of Kelaniya, Sri Lanka \\ University Kandy Road Kelaniya, 11600, Sri Lanka \\ ${ }^{3}$ Department of Anatomy, Faculty of Medicine, University of Wayamba, Sri Lanka \\ B308 Negombo-Kurunegala Rd, 60170, Sri Lanka \\ *Email: prabashi185@gmail.com
}

\begin{abstract}
The different surgical techniques and importance in disease treatment were explored by Sushruta, the father of surgery. Furthermore, Anushastra or parasurgical substances and methods from Ayurveda are distinctive in surgical fields as discovered by Sushruta. Kshara or alkali are useful for performing excision/removal, incision/cutting, scraping, alleviating three Doshas and several special procedures, and therefore superior to Shastra (sharp instruments) or Anu Shastra (accessory apparatuses). Also, Kshara is derived from diverse Ayurveda plants and applied in different ways to manage various diseases, including bhagandara (fistula-in-ano) and other numerous anorectal conditions. This study implemented a literary analysis of the plant sources employed to prepare Kshara sutra. There are 23 Kshara source plants provided by Sushruta. The specimens were identified by a comparison of the description to previously published Kshara sutra references. The data recorded encompassed botanical name, local label, location, pharmacodynamics, morphology characteristics, action, chemical constituents, and antimicrobial activity. There are three source plants provided by Sushruta to prepare Kshara sutra for fistula-in-ano management in this study including Curcuma longa Linn., Commiphora mukul, and Euphorbia antiquorum. It is possible to become a reference for Kshara sutra, a novel drug delivery system in Ayurvedic surgery for anorectal diseases and involves a thread smeared with kshara (alkali) applied to induce both mechanical and chemical cutting and healing.
\end{abstract}

Keywords: Anushastra; Ayurveda; fistula-in-ano; Kshara; Ksharasutra

Article History: Received 02 September 2020; Received in revised form 30 September 2020; Accepted 14 November 2020; Available online 30 December 2020

How to Cite This Article: Samaranayake GVP, Walivita WALC, Chandimal KM. 2020. Literary and analytical study of the source plants of Kshara (Alkali) for Ksharasutra preparation in the management of fistula-in-ano. Biogenesis: Jurnal Ilmiah Biologi. vol 8(2): 234-240. doi: https://doi.org/10.24252/bio.v8i2.17348.

\section{INTRODUCTION}

The different surgical techniques and importance in disease treatment were explored by Sushruta, the father of surgery. Furthermore, Anushastra or parasurgical substances from Ayurveda are distinctive in surgical fields as discovered by Sushruta. Anushastra refers to any substance or procedure capable of use as surgical instruments with minimized invasion and stress on the patients, and is known as hinashastra or shastra sadrushya (Acharya \& Acharya, 2008; Lobo et al., 2012).

Importance of Kshara. According to Susruta Samhita, Kshara or alkali is useful to perform excision/removal, incision/cutting, scraping, alleviation of three Doshas, for various special procedures, and therefore superior to Shastra (sharp instruments) and Anu Shastra (accessory apparatuses) (Ammon \&
Wahl, 1991). Ashtanga Hridaya Samhita posits Kshara is the best of all the sharp equipment, usable in inaccessible places, and performs many functions including incising and excising. Also, this substance is successfully used for difficult to cure diseases, and is capable of application in form of a drink (Banerjee \& Nigam, 1977). Therefore, Kshara or alkali substances are considered one of the most important parasurgical methods.

Kshara is obtained from different Ayurveda plants and applied in diverse ways to manage several diseases, including bhagandara (fistula-in-ano) and other ano-rectal conditions. Ksharasutra, a novel drug delivery system, is commonly used for Ayurvedic surgery in anorectal diseases and involves a thread smeared with kshara applied to induce both mechanical and chemical cutting and healing. Furthermore, 
Sushruta describes an exhaustive list of Kshara source plants, and Kshara of Achyranthes aspera is majorly applied in Ksharasustra preparation. However, different Kshara source plants are suited for individual patients due to the diverse exerted pharmacological behaviour, and therefore, the Prakriti (constitution) of the patients and dosha involvement in the clinical conditions is different.

Types of kshara. Sushruta classified Kshara into two types: Pratisaraniya Kshara and Paaniya Kshara, for external application and internal use respectively.

This study implemented a literary analysis of three plant sources used to prepare Kshara sutra for the management of fistula-in-ano.

\section{MATERIALS AND METHODS}

The specimens were identified by a comparison of the description to previously published Kshara sutra references. The data recorded encompassed botanical name, local label, location, pharmacodynamics, morphology characteristics, action, chemical constituents, and antimicrobial activity.

\section{RESULTS AND DISCUSSION}

The result indicated both Kshara types possess individual indications and precautions, and ksharasutra application resulted in a modified form of Pratisaraniya kshara. Table 1 shows there are 23 list of Kshara source plants provided by Sushruta, while Table 2 further divides this according to the doshas.

The textual description of the plants shows Kshara dravya potential, with individual Rasapanchaka. Therefore, the resulting Kshara is likely to possess diverse set of pharmacological properties and effects, and this causes application in several patients to reduce regular undesirable effects including pain, burning, itching, without affecting the primary aim of fistula- in-ano management.

Properties of Kshara. According to Susruta Samhita; Kshara properties contain several drugs and alleviates the three doshas. Furthermore, the material is colored white, placid (Saumya), but incapable of performing cauterization, digestion and splitting. Also, the content is majorly drugs with heating effect causing a pungent taste, and other characteristics includes heat-making potency, sharp, digestive, dissolving, cleansing, healing, drying, checking and scraping. The material destroys worms, ama Dosha, kapha, skin diseases, poisons, fat, and sexual potency after prolonged administration.

Table 1. List of source plants of Kshara according to Sushruta Samhita (Rath et al., 2012).

\begin{tabular}{|c|c|c|}
\hline Local Name & Botanical Name & Family \\
\hline Mushkka & $\begin{array}{l}\text { Elaeodendron } \\
\text { glaucum Pers. }\end{array}$ & Celastracea \\
\hline Kutaja & $\begin{array}{l}\text { Holarrhena } \\
\text { antidysentrica } \\
\text { Linn }\end{array}$ & Apocynaceae \\
\hline Palash & $\begin{array}{l}\text { Butea } \\
\text { monosperma Linn. }\end{array}$ & Fabaceae \\
\hline Ashwakarna & $\begin{array}{l}\text { Dipterocarpus } \\
\text { turbinatus } \\
\text { Gaertn.F. }\end{array}$ & Dipterocarpacea \\
\hline Paribhadrak & $\begin{array}{l}\text { Erythrina } \\
\text { variegata Linn }\end{array}$ & Fabacea \\
\hline Bibhitaka & $\begin{array}{l}\text { Terminalia } \\
\text { belerica. Roxb }\end{array}$ & Combretacea \\
\hline Aragvadh & $\begin{array}{l}\text { Cassia fistula } \\
\text { Linn. }\end{array}$ & Caesalpinoidae \\
\hline Tilwaka & $\begin{array}{l}\text { Symplocos } \\
\text { racemosa Roxb }\end{array}$ & Symplocaceae \\
\hline Arka & $\begin{array}{l}\text { Calotropis } \\
\text { procera }(\text { Ait }) R . B r .\end{array}$ & Asclepiadaceae \\
\hline Snuhi & $\begin{array}{l}\text { Euphoria nerifolia } \\
\text { Linn. }\end{array}$ & Euphorbiaceae \\
\hline Apamarg & $\begin{array}{l}\text { Achyranthes } \\
\text { aspera Linn }\end{array}$ & Amaranthaceae \\
\hline Patla & $\begin{array}{l}\text { Stereospermum } \\
\text { suaveolens DC. }\end{array}$ & Bignoniaceae \\
\hline Naktamal & $\begin{array}{l}\text { Pongamia pinnata } \\
\text { Pierre. }\end{array}$ & Fabaceae \\
\hline Vrusha & $\begin{array}{l}\text { Adathoda vasica } \\
\text { Nees. }\end{array}$ & Acanthaceae \\
\hline Kadali & $\begin{array}{l}\text { Adathoda vasica } \\
\text { Nees. }\end{array}$ & Acanthaceae \\
\hline Chitraka & $\begin{array}{l}\text { Plumbago } \\
\text { zeylanica Linn. }\end{array}$ & Plumbaginaceae \\
\hline Putika & $\begin{array}{l}\text { Holoptelia } \\
\text { integrifolia Planch }\end{array}$ & Ulmaceae \\
\hline Asphota & $\begin{array}{l}\text { Hemidesmus } \\
\text { indicus } R . B r\end{array}$ & Asclepiadaceae \\
\hline Ashwamarak & $\begin{array}{l}\text { Nerium indicum } \\
\text { Mill }\end{array}$ & Apocynaceae \\
\hline Saptachhada & $\begin{array}{l}\text { Alstonia scholaris } \\
R, B r\end{array}$ & Apocynaceae \\
\hline Agnimantha & $\begin{array}{l}\text { Premna } \\
\text { mucronata Roxb }\end{array}$ & Verbenaceae \\
\hline Gunja & $\begin{array}{l}\text { Abrus precatorius } \\
\text { Linn }\end{array}$ & Fabaceae \\
\hline Koshataki & $\begin{array}{l}\text { Luffa acutangula } \\
\text { Roxb }\end{array}$ & Cucurbetaceae \\
\hline
\end{tabular}


Table 2. List of source plants of Kshara according to Sushruta Samhita, division of plants based on the Doshaghnatva (Rath et al., 2012).

\begin{tabular}{ll}
\hline Vataghna & Kadali \\
\hline Pittaghna & Aragvadha, Krutavedhan, Kutaja \\
& Palash, Karanj, Tilvak, Vasa, \\
& Agnimanth, Apamarg, Snuhi, Putika, \\
& Ashwakarna, \\
& Nimba, Bibhitaka, Karavira, Arka, \\
& Saptachhada, Chitraka, \\
& Krishnamushkaka \\
Tridoshghna & Patala, Sariva, Gunja \\
\hline
\end{tabular}

Indications for Pratisaraniya Kshara (external use of Kshara). The external application is advisable for use against Kustha (ermatoses), Kitibha (hyperkeratosis), ringworm patches, Kilasa (vitiligo), fistula-inAno, tumors, piles, dirty wounds, sinus, warts, moles, birth marks, facial hyperpigmentation, external abscess, worms and poisoning. Furthermore, the substance is recommended as an alternative for sharp apparatuses in several mouth diseases including Upajivha, Adhijivha, Upakusa, Danta Vaidarbha, and three types of Rohani, and is fit for application as subsidiary instruments (Edwin et al., 2008). According to Ashtanga Hiradhaya Samhita, the direct usage of Pratisaraniya Ksharayoga as Kshara comprises Mashaka - moles/warts, Shvitra leukoderma, Bahya Arsha - external piles, Kushta - skin diseases, anesthetic patches, Bhagandara - ano-rectal conditions, Arbuda cancerous growth, Granthi - tumors, fibroids, Dushta Nadi vrana - foul, and sinus ulcers.

Indication of Paniya Kshara. The internal application of alkalis includes treatment for Gara (poisons), abdominal swellings disorders, dyspepsia, indigestion, loss of appetite, constipation, urinary gravel/stones, deep seated abscess, worms and piles (Gayathri et al., 2009).

Paniya Kshara indication. The drinkable form is applicable for treatment of Arsha (haemorrhoids), Agnisada (dyspepsia), Ashma (renal calculus), Gulma (tumors of the abdomen), Udara (ascites/enlargement of the abdomen), Garavisha (chronic poisoning) (Khan et al., 2010). However, where the alkali loses water content, alkali solution is added in quantities for boost (Kimura et al., 2001).
Indications of Three Kinds of Alkali.

Teekshna Kshara - The strong potency alkali is useful for treatment of diseases arising from Vata, Kapha, Medas (fat) Arbuda (cancerous growth) and ailments with high curing difficulty.

Madhyama Kshara - The medium potency alkali is effective in moderate strength diseases with ease in curing.

Mrudu Kshara - The mild alkali is applied for in diseases occurring from Pitta, Asra-Rakta and hemorrhoids.

\section{Source plants of Kshara sutra preparation.}

\section{Achyranthes aspera}

Botanical Name. Achyranthes aspera Linn.

Family. Amaranthaceae

Pharmacodynamics. Taste (Rasa) - pungent (Katu) and bitter (tikta); Qualities (Guna) lightness (Laghu), dryness (Rooksh), strong, sharp; (Teeksna, Vipaka-Katu,Veerya - Ushna (hot potency) effect on Tridosha - balances Kapha and Vata Dosha.

Actions (Karma). Dipana, pachana, krimighna, rochana, sangrahi, pettasaraka, ptittasamshodhaka, durjara, vishtambhi, (bija or seeds), raktaprasdana, hridya, raktashodhaka, raktavardhaka, shothahara, kaphanissaraka, mutrala, ashmarihara, svedajanaka, kandughna, katupaushtika, vedanasthpaka, vishaghna, vranashodhaka, raktarodhaka, shirovirecana, medohara, lekhana, vatakaphaghna, arshoghna.

Morphology. Achyranthes aspera is an erect or procumbent annual or perennial herb with height of about 1- 2 meter, and occasionally a woody base. The stems are angular, ribbed, simple or branched from the base, often with tinged purple colour, while the branches are terete, totally quadrangular, striate or pubescent. Also, the leaves are thick, 3.8-6.3 $\times$ $22.5-4.5 \mathrm{~cm}$ in ovate-elliptic or obovate-round shapes, finely and softly pubescent on both sides, with entire petiolate or petiole $6-20 \mathrm{~mm}$ length. The flowers are greenish white, and numerous axillary or terminal spikes were about $75 \mathrm{~cm}$ long. The seeds are subcylindric, truncate at the apex, rounded at the base and reddish brown. 
Chemical constituents. The content of the leaves, stems and roots were alkaloids, sterol and saponins. Furthermore, the root possess ecdysone, ecdysterone (polypodine A) and insect moulting hormones while the seeds contain saponin $A \& B$. The fruit comprises two oleanolic acid based saponins. Also, the plant encompasses an alkaloid achyranthine (betaine), amino acids, arginine, histidine, lysine, cystine, threonine, methionine, lucine, isolucine, phenylalanine, tryptophan and carbohydrate, valine, $\alpha$-rhamnopyranosyl, $\beta-\mathrm{D}$ gluuronopyranosyl, B-D galactopyranosyl, galactose, xylose, rhamnose and glucose, large amount of potash, hormones, ecdysterone and inokosterone.

Antimicrobial Activity. Khan et al. (2010) reported an indication of mild to moderate antibiotic activity against $B$. subtilis, $E$. coli and $P$. aeruginosa in the ethanol and chloroform extracts of Achyranthes aspera seeds. The studies of Prasad et al. (2016) revealed antimicrobial action from the various extracts of the plant leaves and callus. Misra et al. (1992) discovered 17-pentatriacontanol was a major constituent isolated from essential oil of the plants sprouts, and showed antifungal activity against Asperigillus carneus (Prasad et al., 2016). Antibacterial and antifungal effect against various pathogenic strains including $E$. coli, $P$. aeruginosa, Citrobacter sp., B. subtilis, Micrococcus sp., Klebsiella sp. using disk diffusion and well-plate method (Malarvili \& Gomathi, 2009; Manjula et al., 2009; Samaranayake et al., 2020). The extracts indicated maximum inhibition of E. coli (17 $\mathrm{mm}$ ), followed by species of Pseudomonas (14 $\mathrm{mm})$, Citrobacter $(12 \mathrm{~mm})$, Bacillus $(12 \mathrm{~mm})$ and Micrococcus (12 mm). Also, predominant prevention from gram negative bacteria at a higher concentration of $50 \mu \mathrm{g} / \mathrm{ml}$ was displayed (Saravanan et al., 2008).

Antioxidant Activity. Tahiliani \& Kar (2000) researched several leaves extracts for antioxidant effect, and Gayathri et al. (2009) found this in the leaves and roots while Malarvili \& Gomathi (2009) reported this in seeds. Therefore, the presence of phytoactive constituents is found in Achyranthes aspera (Sharma, 1977). The phytoactive component caused reduction in lipid peroxidation rate, and enhancement in free radical scavenging activity of the herbal seed powder.

Wound Healing Activity. Edwin et al. (2008) explored the ethanolic and aqueous extracts of the leaves for injury healing potential, using two wound models comprising excision and incision.

Curcuma longa Linn.

Family. Scitaminaceae

Sanskrit names. Haridra, Nisha

Pharmacodynamics. Rasa-Tikta, Katu,GunaRuksa, Laghu, Virya-Ushna, Vipaka-Katu, Dosha karma-Kapha-vatashamaka, Pittarechaka-shamaka

Actions (Karma). Vamya,Krimighna,tvachya, mukhakantikara,

kushtaghna, vedanasthapana, raktaprasadhaka, dehavarnaprada, vranaropana, vranashodhana, lekhana, mustrasangrahaniya, mutravirajaniya, garbhashayashodhana, stanyashodhana, shukrasodhana, hikkanigrahana, anulomana, arshoghna, tvakdoshahara.

Morphology. A tall herb with large rootstalk, ovoid in shape and possessing sessile cylindrical tubers colored orange inside. Furthermore, the leaves are very large with tufts length of 1.2 meters or more, including the petiole with similar measurement as the blade, oblong-lanceolate, and tapering to the base. The flowers had autumnal spikes of $10-15 \mathrm{~cm}$ length, peduncle of $15 \mathrm{~cm}$ or more, concealed by the sheathing petiole while the flowering bracts were pale green and the coma tinged with pink.

Pharmacology. Curcumin (I, II, III) is a major component in Curcuma longa, and responsible for the biological actions. Furthermore, this exhibits anti-parasitic, anti-spasmodic, antiinflammatory and gastro-intestinal effects in vitro, and constrains carcinogenesis and cancer growth in parental and oral application on animal models. According to Araújo \& Leon (2001), the extraction of dried powder with 95\% ethanol yielded cured ethanol extract of $29.52 \%(\mathrm{w} / \mathrm{w})$ containing curcumin $(11.6 \%)$, demothxycurcumin $\quad(10.32 \%), \quad$ and 
bisdemothxycurcumin. The agar disc diffusion method was employed to test this for antifungal effect against 29 clinical strains of dermatophytes, and an inhibition zone range of 6.1 to $26.0 \mathrm{~mm}$ was found. Wuthi-Udomlert et al. (2000) discovered improved cutaneous wound healing in rats and guinea pigs by curcumin (diferuloymethane), a natural product derived from $C$. longa rhizomes. Also, the animal injuries treated with oral and tropical curcumin in diabetic model indicated timelier re-epithelialisation, improved neovascularisation, enhanced migration of several cells including dermal myo-fibroblasts and macrophages into the wound bed, and a higher collagen content (Sidhu et al., 1999). Furthermore, the popular ability of the transforming growth factor beta 1 to enhance wound healing is likely due to curcumin.

The $C$. longa extract exhibited an antiinflammatory action in standard animal models, partly due to curcuminoids, turmerones and the volatile oil (Aggarwal et al., 2013; Krup et al., 2013). In addition, the antibacterial activity of the essential oil is significant, and relatively better against Staphylococcus aureus (Teow et al., 2016), Salmonella paratyphi (Kodjio et al., 2016), Mycobacterium tuberculosis (Bai et al., 2016), Proteus mirabilis (Prywer \& Torzewska, 2012) Klebsiella pneumoniae (Bansal \& Chhibber, 2010), while the curcuminoids at $5 \mathrm{mg} / \mathrm{kg}$, turmerones at $0.05 \mathrm{~mL} / \mathrm{kg}$ dose levels, oil-free aqueous extract of $C$. longa at $45 \mathrm{mg} / \mathrm{kg}$ was revealed as the minimum dose required for considerable anti-inflammatory effects (Bagad et al., 2013).

\section{Commiphora wightii (Arn.) Bhandari/ Commiphora mukul (Hook. ex Stocks) \\ Family. Burseraceae \\ Sanskrit names. Guggulu}

Morphology. Shrubby, pubescent, with 1.2-1.3 $\mathrm{m}$ and glandular young parts. The branches are knotty and crooked, with divaricate normally ending in a sharp spine. The flowers are triangular, tube has 2-5 fascicles, with brownish red petals, broadly linear, nearly thrice of calyx length, and possessing reflexes at the apex. There are 8-10 stamens, alternatively long and short, and half the petals length. The disk are 8-
10 lobed, alternate deeper sinuses with insertion of shorter stamens, and ovary oblong-ovoid, attenuated into the style

Pharmacodynamics. Rasa-Katu, Tikta, Madhura, Kashaya, Guna-Laghu, Ruksha, Tikshna, Snigdha, Picchila, Sara, Virya-Ushna, Vipaka-Katu, Dosha karma -Tridosha hara Actions (Karma). Vedanasthapana, nadibalya, vatashamaka, shothahara, vransashodhana, vranaropana, jantughna, dipana, pachana, yakrit uttejaka, arshoghna, krimghna, hridya, rakta-svetakana vardhana, raktaprasadana, kaphanissaraka, sandhaniya, dourgandhyahara, putihara, mutrala, ashmaribhedana, kamottejaka, artavajanana, vandhyatvadoshahara, kushtaghna, varnya, tvachya, shiaprashamana virshya.

Pharmacology. The segment of Guggulu containing oleoresin possessed significant antiarthritic and anti-inflammatory attributes, and the minimum effective dose is $12.5 \mathrm{gm} / 100 \mathrm{gm}$ per body weight (Pillai \& Santhakumari, 1981; Sunarwidhi et al., 2014). In addition, a novel triterpene isolated from Guggulu gum resin is myrrhanol A, and exhibits strong antiinflammatory effect on exudative pouch fluid, angiogenesis and granuloma weights in adjuvant-induced air pouch granuloma of mice. However, the effects were more apparent in hydrocortisone and $50 \%$ aqueous methanolic crude drug extract (Kimurai et al., 2001).

The aqueous resin extract of Commiphora mukul substantially constrains both the maximal and total oedema response during 6 hours of carrangeenan-induced rat paw edema. Also, daily administration of mansumbinoic acid at a single dose level of $1.5 \times 10(-4) \mathrm{mol} \mathrm{kg}$ 1 considerably minimized joint swelling in adjuvant arthritis in rats. The essential oil was fungistatic or fungicidal to the moulds of Aspergillus flavus, A. furnigatus, A. sulphueus, Mucor fragilis and Rhizopus stolonifer, based on the concentration (Sarbhoy et al., 1978). The application of Guggulu caused reduction in oedema $(37.14 \%)$ compared to prednisolone (43.60\%); fluid volume by $54.98 \%$, contrasted with prednisolone $(64.5 \%)$, and granuloma pouch weight was $60.80 \%$ measured against prednisolone $(71.47 \%)$. For five months, antiinflammatory agents including 
phenylbutazone, ibuprofen and fraction of gumguggulu derived from $C$. mukul were administered orally resulted in decreased thickness of joint swelling, proving the beneficial role in arthritis research (Sharma, 1977). Guggulu resin fraction at a dose of 300 $\mathrm{mg}$ inhibits $30 \%$ of acetylcholine effect. This almost entirely blocked the impact of agonists comprising acetylcholine, histamine, bradykinin and 5-hydroxyl-tryptamine, while intra-peritoneal administration of resin fraction of C. mukul resulted in statistically significant percentage inhibition of oedema (Sharma, 1977).

\section{Euphorbia antiquorum}

Family. Euphorbiaceae

\section{Sanskrit names. Snukhi}

Pharmacodynamics. Rasa-Katu, Guna-Lagu, Snigdha, tikshna, Veerya-Ushna Vipaka-Katu

Actions (Karma). Alleviate Vata \& Kapha. Purgative. Promote appetite (medas kshaya), reduce fat tissue, cure pain, Ama dosha, Ashtilika, flatulence, Gulma, stomach disorders, skin diseases, piles, edema, urinary calculi, anemia (pandu), wounds, fever, splenic disorder, poisoning. Latex-applicable as purgative for persons suffering from Gulma, Kushta, Udara \& other long-lasting diseases.

Morphology. A large shrub or small, spinous tree of 4.5-9 m, white latex. The numerous branches curve upwards, stout, fleshy, green, jointed and thick sinuate wings of 3-5 width. The leaves are 6-13 mm, subsessile, obovateoblong, fleshy, deciduous while the spines are stipular, short, divaricate. Hemispherical involucres, yellow, 3-nate, forming small pedunculate cymes in the sinuses, with the central flower sessile and female.

Chemical constituents. The content of the latex in the branches comprise $\beta$-amyrin, cycloartenol, euphol, euphadienol and euphorbol. The juice encompasses diterpene esters, euphorbin while the stem-bark and latex possess triterpenoids, taraxerol and taraxerone, friedelanol and epi-friedelanol, euphol. Also, the roots contain taraxerol.

\section{CONCLUSION}

There are three source plants provided by Sushruta to prepare Kshara sutra for fistula-in- ano management in this study including Curcuma longa Linn., Commiphora mukul, and Euphorbia antiquorum.

\section{REFERENCES}

Acharya VJT, Acharya NR. 2008. Sushruta, Sushruta samhita, Chikitsa Sthana, Bhagandara Chikitsa Adhyaya. $1^{\text {st }}$ ed. Vol. 8. Varanasi: Chaukhambha Surabharati Prakashan. p. 441

Aggarwal BB, Yuan W, Li S, Gupta SC. 2013. Curcumin free turmeric exhibits anti-inflammatory and anticancer activities: Identification of novel components of turmeric. Molecular Nutrition \& Food Research. vol 57(9): 1529-1542. doi: https://doi.org/10.1002/mnfr.201200838.

Ammon HP, Wahl MA. 1991. Pharmacology of Curcuma longa. Planta Med. vol 57 (1) 1-7. doi: https://doi.org/10.1055/s-2006-960004.

Araújo CC, Leon LL. 2001. Biological activities of Curcuma longa L. Memórias do Instituto Oswaldo Cruz. vol 96(5): 723-728. doi: https://doi.org/10.1590/s007402762001000500026.

Bagad AS, Joseph JA, Bhaskaran N, Agarwal A. 2013. Comparative evaluation of anti-inflammatory activity of curcuminoids, turmerones, and aqueous extract of Curcuma longa. Advances in Pharmacological Sciences. vol 2013: 1-8. doi: https://doi.org/10.1155/2013/805756.

Bai X, Oberley-Deegan RE, Bai A, Ovrutsky AR, Kinney WH, Weaver M, Zhang G, Honda JR, Chan ED. 2016. Curcumin enhances human macrophage control of Mycobacterium tuberculosis infection. Respirology. vol 21(5): 951-957. doi: https://doi.org/10.1111/resp.12762.

Banerjee A, Nigam SS. 1977. Antibacterial efficacy of the essential oil derived from the various species of the genus- Curcuma Linn. Journal of Research and Education in Indian Medicine. vol 12(1): 1.

Bansal S, Chhibber S. 2010. Curcumin alone and in combination with augmentin protects against pulmonary inflammation and acute lung injury generated during Klebsiella pneumoniae B5055induced lung infection in BALB/c mice. Journal of Medical Microbiology. vol 59(4): 429-437. doi: https://doi.org/10.1099/jmm.0.016873-0.

Edwin S, Jarald EE, Deb L, Jain A, Kinger H, Dutt KR, Raj AA. 2008. Wound healing and antioxidant activity of Achyranthes aspera. Pharmaceutical Biology. vol 46(12): 824-828. doi: https://doi.org/10.1080/13880200802366645.

Gayathri DS, Archanah A, Abiramasundari P, Priya V, Uma K, Abirami T. 2009. Pharmacological activities of Achyranthes aspera, an overview. Indian Journal of Nutrition and Diebetics. vol 46(12): 485-490.

Khan MTJ, Ahmad K, Alvi MN, Mansoor B, Saeed MA, Khan FZ, Jamshaid M. 2010. Antibacterial and irritant activities of organic solvent extracts of 
Agave americana Linn., Albizzia lebbek Benth., Achyranthes aspera Linn. and Abutilon indicum Linn-A preliminary investigation. Pakistan Journal of Zoology. vol 42(1): 93-97.

Kimura I, Yoshikawa M, Kobayashi S, Sugihara Y, Suzuki M, Oominami H, Murakami T, Matsuda H, Doiphode VV. 2001. New triterpenes, myrrhanol A and myrrhanone $\mathrm{A}$, from guggul-gum resins, and their potent anti-inflammatory effect on adjuvantinduced air-pouch granuloma of mice. Bioorganic \& Medicinal Chemistry Letters. vol 11(8): 985989. doi: https://doi.org/10.1016/S0960894X(01)00111-1.

Kodjio N, Atsafack SS, Fodouop SP, Kuiate JR, Gatsing D. 2016. In vitro antisalmonellal and antioxidant activities of extracts and fractions of Curcuma longa L. rhizomes (Zingiberaceae). International Journal of Biochemistry Research \& Review. vol 11(3): 1-4. doi: https://doi.org/10.9734/IJBCRR/2016/25106.

Krup V, Prakash LH, Harini A. 2013. Pharmacological activities of turmeric (Curcuma longa Linn): a review. Journal of Homeopathy \& Ayurvedic Medicine. vol 2(4): 1-4. doi: http://dx.doi.org/10.4172/2167-1206.1000133.

Lobo SJ, Bhuyan C, Gupta SK, Dudhamal TS. 2012. A comparative clinical study of Snuhi Ksheera Sutra, Tilanala Kshara Sutra and Apamarga Kshara Sutra in Bhagandara (fistula in ano). Ayu. vol 33(1): 85 91. doi: https://dx.doi.org/10.4103\%2F09748520.100319.

Malarvili T, Gomathi N. 2009. Effect of Achyranthes aspera (Linn) seeds on redox and oxidative status in plasma and selected tissues of rats fed with high doses of fructose. Biosciences, Biotechnology Research Asia. vol 6(2): 659-664.

Manjula M, Indira V, Dhasarathan P. 2009. Phytochemical characterization and antibacterial activity screening of Achyranthes aspera. Asian Journal of Microbiology, Biotechnology \& Environmental Sciences Paper. vol 11(2): 365-368.

Misra TN, Singh RS, Pandey HS, Prasad C, Singh BP. 1992. Antifungal essential oil and a long chain alcohol from Achyranthes aspera. Phytochemistry. vol 31(5): 1811-1812. doi: https://doi.org/10.1016/0031-9422(92)83153-P.

Pillai NR, Santhakumari G. 1981. Hypoglycaemic activity of Melia azadirachta Linn (neem). Indian Journal of Medical Research. vol 74: 931-933.

Prasad SHKR, Swapna NL, Anthonamma K, Rajasekhar,D. 2016. Antimicrobial activity of Achyranthes aspera and Aerva lanata leaf and callus extracts. Biosciences Biotechnology Research Asia. vol 6(2): 887-891.

Prywer J, Torzewska A. 2012. Effect of curcumin against Proteus mirabilis during crystallization of struvite from artificial urine. Evidence-Based Complementary and Alternative Medicine. vol 2012: $1-8$. doi: https://doi.org/10.1155/2012/862794.
Rath SK, Nagar L, Sinde A, Gahunge P, Lamo R, Khemani N. 2012. Review of source plants of kshara for kshara sutra preparation for the management of fistula-in-ano. International Journal of Research in Ayurveda \& Pharmacy. vol 3(3): 333-340.

Samaranayake GVP, Pushpakumara AAJ, Pieris KPP. 2020. Comparative study on different treatment modules in the management of fistula-in-ano. International Journal of Current Advanced Research. vol 9(6): 22407-22411. doi: http://dx.doi.org/10.24327/ijcar.2020.22411.4417.

Saravanan P, Ramasamy V, Shivakumar T. 2008. Antimicrobial activity of leaf extracts of Achyranthes aspera Linn. Asian Journal of Chemistry. vol 20(1): 1-3.

Sarbhoy AK, Varshney JL, Maheshwari ML, Saxena DB. 1978. Efficacy of some essential oils and their constituents on few ubiquitous molds. Zentralblatt für Bakteriologie, Parasitenkunde, Infektionskrankheiten und Hygiene. Zweite Naturwissenschaftliche Abteilung: Mikrobiologie der Landwirtschaft, der Technologie und des Umweltschutzes. vol 133(7-8): 723-725.

Sharma JN. 1977. Comparison of the anti-inflammatory activity of Commiphora mukul (an indigenous drug) with those of phenylbutazone and ibuprofen in experimental arthritis induced by mycobacterial adjuvant. Arzneimittel-forschung. vol 27(7): 14551457.

Sunarwidhi AL, Sudarsono S, Nugroho AE. 2014. Hypoglycemic effect of combination of Azadirachta indica A. Juss. and Gynura procumbens (Lour.) Merr. ethanolic extracts standardized by rutin and quercetin in alloxaninduced hyperglycemic rats. Advanced Pharmaceutical Bulletin. vol 4(2): 613-618. doi: https://dx.doi.org/10.5681\%2Fapb.2014.090.

Sidhu GS, Mani H, Gaddipati JP, Singh AK, Seth P, Banaudha KK, Patnaik GK, Maheshwari RK. 1999. Curcumin enhances wound healing in streptozotocin induced diabetic rats and genetically diabetic mice. Wound Repair and Regeneration. vol 7(5): 362-374. doi: https://doi.org/10.1046/j.1524475X.1999.00362.x.

Tahiliani P, Kar A. 2000. Achyranthes aspera elevates thyroid hormone levels and decreases hepatic lipid peroxidation in male rats. Journal of Ethnopharmacology. vol 71(3): 527-532. doi: https://doi.org/10.1016/S0378-8741(00)00170-7.

Teow SY, Liew K, Ali SA, Khoo ASB, Peh SC. 2016. Antibacterial action of curcumin against Staphylococcus aureus: a brief review. Journal of Tropical Medicine. vol 2016: 1-11. doi: https://doi.org/10.1155/2016/2853045.

Wuthi-Udomlert M, Grisanapan W, Luanratana O, Caichompoo W. 2000. Antifungal activity of Curcuma longa grown in Thailand. The Southeast Asian journal of Tropical Medicine and Public Health. vol 31: 178-182. 